\title{
Impact of nanophos in agriculture to improve functional bacterial community and crop productivity
}

Parul Chaudhary ${ }^{1 *}$, Anuj Chaudhary ${ }^{2}$, Heena Parveen ${ }^{1}$, Alka Rani $^{3}$, Govind Kumar $^{4}$, Rajeew Kumar ${ }^{5}$ and

Anita Sharma ${ }^{1}$

\begin{abstract}
Background: Since the World's population is increasing, it's critical to boost agricultural productivity to meet the rising demand for food and reduce poverty. Fertilizers are widely used in traditional agricultural methods to improve crop yield, but they have a number of negative environmental consequences such as nutrient losses, decrease fertility and polluted water and air. Researchers have been focusing on alternative crop fertilizers mechanisms to address these issues in recent years and nanobiofertilizers have frequently been suggested. "Nanophos" is a biofertilizer and contains phosphate-solubilising bacteria that solubilises insoluble phosphate and makes it available to the plants for improved growth and productivity as well as maintain soil health. This study evaluated the impact of nanophos on the growth and development of maize plants and its rhizospheric microbial community such as NPK solubilising microbes, soil enzyme activities and soil protein under field condition after 20, 40 and 60 days in randomized block design.

Results: Maize seeds treated with nanophos showed improvement in germination of seeds, plant height, number of leaves, photosynthetic pigments, total sugar and protein level over control. A higher activity of phenol, flavonoid, antioxidant activities and yield were noticed in nanophos treated plants over control. Positive shift in total bacterial count, nitrogen fixing bacteria, phosphate and potassium solubilizers were observed in the presence of nanophos as compared to control. Soil enzyme activities were significantly $(P<0.05)$ improved in treated soil and showed moderately correlation between treatments estimated using Spearman rank correlation test. Real time PCR and total soil protein content analysis showed enhanced microbial population in nanophos treated soil. Obtained results showed that nanophos improved the soil microbial population and thus improved the plant growth and productivity.
\end{abstract}

Conclusion: The study concluded a stimulating effect of nanophos on Zea mays health and productivity and indicates good response towards total bacterial, NPK solubilising bacteria, soil enzymes, soil protein which equally showed positive response towards soil nutrient status. It can be a potential way to boost soil nutrient use efficiency and can be a better alternative to fertilizers used in the agriculture.

Keywords: Maize, Nanophos, NPK solubilizers, Protein, Soil enzyme activities

*Correspondence: parulchaudhary1423@gmail.com

1 Department of Microbiology, College of Basic Sciences and Humanities,

G.B. Pant University of Agriculture and Technology, Pantnagar,

Uttarakhand, India

Full list of author information is available at the end of the article

\section{Background}

Present agricultural practices face major challenges like decline in agricultural productivity and deterioration in sustainability of agro-ecosystem worldwide. Food production cannot be sustainable unless a soil has a sufficient and proactive microbial population [1]. Maize 
(Zea mays L.) is the major food globally and known as the queen of cereal crops. However, agricultural yield of major crops is severely low due to injudicious application of agrochemicals and nutrient insufficiency that rigorously affects overall plant and soil health. Thus, there is a need to focus on good quality agronomic practices.

Agricultural sector is growing progressively with the introduction and implementation of innovative tools and techniques such as nanomaterials, nanofertilizer and nanobiofertilizers. Nanotechnology is an innovative field of science with applications in a variety of fields, including food and agriculture [2]. Nano materials having high surface tension holds the material more strongly than conventional surfaces thus helps in slow release of fertilizers makes them useful in agricultural sector [3]. Combined application of bioformulated plant useful microorganisms and nanocompounds were traditionally used as an effective replacement for chemical fertilizers in ancient times.

Phosphorus is essential nutrients required in adequate amount by plants but present in unavailable form. It is required for proper plant growth and development. Plants could enhance P uptake from the soil by varying root morphology [4]. Physiological changes like release of organic acids, release of protons, phenolics, phytase and phosphatase enzymes increase the $P$ availability in the rhizosphere. Therefore, phytase and phosphatase enzymes released by microbes and roots help in mineralization of $\mathrm{P}$ and easily available to plants. Phosphorus solubilising microbes (PSM) is microbial fertilizers with broad prospective and nanophos in form of liquid formulation helps in root proliferation and controls soil borne pathogens. It also increases the capacity of the plant for up taking of nutrients, increases the seed germination, maturity ratio of grain and yield.

Importance of bioformulations using bioinoculants in agricultural sector is well known [5]. They assist in nutrient acquisition through nitrogen fixation, siderophore production, Hydrogen cyanide production $(\mathrm{HCN})$ and phosphate solubilization thus supporting plant growth $[6,7]$. PGPR have been studied and many biofertilizers are commercialized in the market such as the species Pseudomonas, N fixing Azospirillum and Bacillus [8]. There are various PSB such as Pseudomonas taiwanensis, Pantoea agglomerans, Bacillus and Sinorhizobium [9]. However, widespread application of biofertilizers by farmers is still limited. Certain challenges are associated with product development under optimized lab conditions to their wide application in fields like inconsistency of PGPR and inadequate shelf life of bioinoculants [10]. Nanoencapsulation of biofertilizers using natural polymers could be used as a versatile tool in enhancing the shelf life of PGPR [11]. In addition, nanoparticles assist in controlled release of nutrients that prevents leaching and evaporation of harmful substances. This in turn maintains the soil fertility and useful soil microflora. PGPB can be applied on seeds by various formulations (liquid, organic and inorganic) and influence the bio stimulant effectiveness [12].

Soil microbes such as PSB and nitrogen fixing bacteria help in restoration of soil fertility by nutrients cycling and ultimately help in plant growth [13]. Application of Rhizobium and Stenotrophomonas maltophila improved the plant growth due to increased $\mathrm{P}$ availability under saline condition [14]. PSB have been used as a biofertilizers in various crop such as maize, cabbage and sugarcane $[15,16]$. Soil enzymes, microbial population and micro/ macronutrients determined the functions of microbial community and have huge impact in maintaining soil fertility. Soil enzymes reveal the changes in soil biochemical processes and deviation in soil due to environmental factors. Estimation of soil enzyme activities in nutrient cycling has been extensively used as indicator to find out any changes by environmental/human issues [17]. These enzymes are derived from plant root exudates, animal residues and soil microbes. They play a vital role in catalysing reactions required for nutrient cycling, organic matter decomposition and stabilize soil structure. FDA, dehydrogenase, amylase and alkaline phosphates enzymes are involved in different nutrient cycling in soil such as nitrogen, carbon and phosphorus. Phosphatases catalyse the ester and anhydride hydrolysis and release free phosphate in the soil. Inoculation of biofertilizers improved the sugarcane yield, acid phosphatase activity and P content in soil over control [18].

This study was conducted to assess the impact of nanophos on maize plants growth, productivity and soil fertility under field condition. The main objectives of the study were to assess the impact of nanophos on different growth parameters of maize plants like seed germination, plant height, chlorophyll, carotenoid, protein, sugar, phenolics content, yield of maize and soil health parameters like NPK bacterial count, soil enzymes activities and evaluate bacterial population of maize rhizosphere using qPCR and soil microbial protein.

\section{Material and methods}

\section{Experimental design}

Field trial was conducted in the month of June to September, (2017) at Norman E Borlogue Crop Research Centre, Govind Ballabh Pant University of Agriculture \& Technology, Pantnagar. Experimental section lies about $30 \mathrm{Km}$ Southward of Shivalik Himalayas (location $79.3^{\circ}$ $\mathrm{E}$ and $29^{\circ} \mathrm{N}$ latitude). Summers are hot and warm in this area with maximum $35^{\circ} \mathrm{C}$ temperature in month of July and minimum $23^{\circ} \mathrm{C}$ during month of September. Relative 
humidity was maximum in month of July and lowest in June. Soil of the experimental site was silty clay type having the $(0.206 \mathrm{dS} / \mathrm{m})$ Electrical conductivity, Organic carbon $(0.78 \%)$, nitrogen, phosphorus, potassium $(215.79,27$ and $136 \mathrm{Kg} / \mathrm{ha}$ ) and having $\mathrm{pH} 7.4$ [19]. Total two treatments: control (without nanophos) and nanophos only were used with three replications each in randomized block design. Each plot has $4.2 \mathrm{~m}$ length and $3.5 \mathrm{~m}$ width with plant-to-plant distance was $20 \mathrm{~cm}$ and row to row was $60 \mathrm{~cm}$.

\section{Seed priming with nanophos}

Nanophos used in this study were provided by Department of Agronomy, GBPUA\&T, Pantnagar. It is unique liquid formulation in combination with nanophosphorus and phosphate solubilising bacteria. High yielding seed variety (Zea mays L. cv. DH296), was obtained from Crop Research Centre, GBPUA\&T. Before sowing for germination, maize seeds were properly sterilized using $70 \%$ ethanol, followed by $3 \%$ hydrogen peroxide. Seeds were washed five times with distilled water and further treated with Nanophos. Viable count for liquid formulation was $1 \times 10^{8}$ cells $/ \mathrm{ml}$ of liquid. Four hundred fifty microlitres nanophos was added in $5 \mathrm{ml}$ distilled water and maize seeds were dipped. After proper treatment, seeds were shade dry for $10-15 \mathrm{~min}$. Treated seeds were used further for field experiment [20]. Control did not receive any treatment.

\section{Seed germination assay}

The seed germination efficacy was tested on Zea mays seeds using the formula:

$$
\text { Germination } \%=\frac{\text { Number of seedlings germinated }}{\text { Total number of seeds }} \times 100
$$

\section{Growth measurement}

Average plant height, root length and number of leaves were measured after 20, 40 and 60 days of the experiment to check the effect of nanophos on growth profile of Zea mays.

\section{Estimation of total chlorophyll and carotenoid content}

Photosynthetic pigment in treated leaf samples were estimated through Dimethylsulfoxide (DMSO) method given by Hiscox and Israelatum [21]. After harvesting, maize leaves were collected, washed with distilled water and finely chopped for experiment. For chlorophyll extraction $500 \mathrm{mg}$ leaves were mixed with $10 \mathrm{ml}$ of DMSO. Then, tubes were properly incubated at $60^{\circ} \mathrm{C}$ for $2 \mathrm{~h}$ in a water bath. Supernatant with extract were pooled and absorbance were taken at 645 and $663 \mathrm{~nm}$. Same treated extract was used for measuring carotenoid content by taking absorbance at $470 \mathrm{mn}[22]$.

\section{Total sugar content}

Method given by Dubois et al. [23] was used to estimate total sugar in maize leaves using glucose as a standard curve. Dried leaves were crushed and added to $3 \mathrm{ml}$ of ethyl alcohol (80\%) and placed in boiling water bath. Homogenate was centrifuged at $1000 \mathrm{rpm}$ for $15 \mathrm{~min}$. Supernatant $(1 \mathrm{ml})$ was transferred in a test tube and Anthrone reagent $(4 \mathrm{ml})$ was added and placed in boiling water for $10 \mathrm{~min}$. Absorbance of each sample was taken at $620 \mathrm{~nm}$ and total sugar was extrapolated against glucose standard curve.

\section{Estimation of total protein}

Crushed leaves $(500 \mathrm{mg})$ were homogenized with $5 \mathrm{ml}$ Tris $\mathrm{Cl}(0.2 \mathrm{M})$ and centrifuged at $10,000 \mathrm{~g}$ for $15 \mathrm{~min}$ at $4^{\circ} \mathrm{C}$. Extracted supernatant $(20 \mu \mathrm{l})$ was taken and $300 \mu \mathrm{l}$ of double distilled water was added to bring up the volume. Bradford dye was added to the tubes and properly mixed by vortex. After incubation for few minutes absorbance was recorded at OD $595 \mathrm{~nm}$ against a blank ( $100 \mu \mathrm{l}$ of extraction buffer with $1 \mathrm{ml}$ of reagent dye) in a spectrophotometer [24].

\section{Determination of total phenolic content in maize leaves}

Total phenolics in treated leaf samples were determined by Folin- Ciocalteu reagent by following method of Ainsworth and Gillespie [25]. Leaf extract $(0.5 \mathrm{ml})$ was mixed with $2 \mathrm{ml}$ of FC reagent. Mixture was incubated for $30 \mathrm{~min}$ at $37^{\circ} \mathrm{C}$ till blue colour develops. The reading of the resultant blue colour was measured at $765 \mathrm{~nm}$. Gallic acid was taken for making standard.

\section{Catalase activity}

Leaf samples from different treatments were homogenized with $5 \mathrm{ml}$ phosphate buffer (100 mM; pH7.5). Extract was centrifuged at $4{ }^{\circ} \mathrm{C}$ for $10 \mathrm{~min}$ at $12,000 \mathrm{rpm}$. Supernatant was further used for enzyme assay. Assay mixture used for the experiment contained phosphate buffer and $0.1 \mathrm{ml}$ of $10 \mathrm{mM} \mathrm{H}_{2} \mathrm{O}_{2}$ and $100 \mu \mathrm{l}$ of enzyme extract.CAT activity was observed through decline in absorbance at $230 \mathrm{~nm}$ for $3 \mathrm{~min}$ corresponding to the decomposition of $\mathrm{H}_{2} \mathrm{O}_{2}$ [26].

\section{Peroxidase (POD) activity}

Enzyme activity was performed using the method given by Mali et al. [27]. For peroxidase activity, $0.1 \mathrm{ml}$ of enzyme extract was added to the assay mixture. The assay mixture contained $0.5 \mathrm{ml} \mathrm{H}_{2} \mathrm{O}_{2}$ and pyrogallol $(0.4 \mathrm{ml})$ prepared in phosphate buffer. Peroxidase activity was measured by observing vary in absorbance at 
$420 \mathrm{~nm}$ and calculated using the extinction coefficient of $26.6 \mathrm{mM}^{-1} \mathrm{~cm}^{-1}$.

\section{Superoxidase activity (SOD)}

Enzyme activity was assessed by using methionine $(200 \mathrm{mM}), 75 \mathrm{mM}$ riboflavin, phosphate buffer $(100 \mathrm{mM}$, $\mathrm{pH}-7.5)$ and enzyme extract $(100 \mu \mathrm{l})$. The activity of the SOD enzyme was by inhibition of NBT and estimated spectrophotometrically at $560 \mathrm{~nm}$ [28].

\section{Collection of soil samples}

Maize plants were collected and gently shaken to remove maize rhizospheric soil $(1-15 \mathrm{~cm}$ depth) for further experiment after 20, 40 and 60 days of sowing. Soil samples $(10 \mathrm{~g})$ from each replicate was taken and kept in sterilized polythene bags. Final sample were prepared by mixing individual samples after homogenization. Soil samples were sieved and used for evaluating chemical and physical properties and indicator enzymes of the soil and stored at $-20^{\circ} \mathrm{C}$ for further analysis.

\section{Enumeration of total bacteria, nitrogen fixers, phosphorus} and potassium solubilizers in treated soil

Bacterial count was checked using different types of media such as nutrient agar for total bacterial count, Ashby agar for nitrogen fixing bacteria, Aleksandrow agar for potassium solubilizers and Pikovaskaya agar for P solubilising bacteria. Plates were incubated for 2-4 days at $30^{\circ} \mathrm{C}$. Colony Forming Unit (CFU) was measured using pour plating method.

\section{Soil health indicator enzymes}

\section{Fluorescein diacetate hydrolytic (FDA) activity}

One gram of soil, $50 \mathrm{ml}$ sodium phosphate buffer (pH-7.6), $0.5 \mathrm{ml}$ FDA solution were as added in a flask and kept for $1 \mathrm{~h}$ at $24^{\circ} \mathrm{C}$ in incubator shaker. To stop the reaction, $2 \mathrm{ml}$ of acetone was added. For $5 \mathrm{~min}$, the soil suspension was centrifuged at $8000 \mathrm{rpm}$. Filter paper No.2 was used to filter the supernatant. FDA hydrolysis was assessed at $490 \mathrm{~nm}$ and represented as ug fluorescein $\mathrm{g}^{-1}$ dry soil $\mathrm{h}^{-1}$ [29].

\section{Dehydrogenase activity in soil}

An important soil health indicator enzyme dehydrogenase was estimated as per the method given by Casida et al. [30] using 2,3,5-Triphenyl tetrazolium chloride (TTC) substrate. Briefly, TTC substrate with pH 7.4 was added to soil sample and incubated in rotatory shaker. Reaction was allowed and terminated at different time intervals using $25 \mathrm{ml}$ acetone. Suspension was centrifuged at $4000 \mathrm{rpm}$ for $15 \mathrm{~min}$ at $4{ }^{\circ} \mathrm{C}$ and filtered using Whatman filter paper no.1. Production of dehydrogenase in soil samples were quantified by measuring insoluble product red product Triphenylformazan (TPF) formed during the reaction. Red coloured TPF can be quantified at the range of visible light $(485 \mathrm{~nm})$.

\section{Alkaline phosphatase activity}

Soil phosphatase activity in the experimental soil was performed using $\mathrm{p}$ - nitrophenyl phosphate as per method given by Tabatabai and Bremer [31]. Briefly, soil sample was added to $250 \mu \mathrm{l}$ toluene followed by addition of universal buffer $(100 \mathrm{mM}, \mathrm{pH} 11)$. To this solution, $1 \mathrm{ml}$ Triphenylformazan (TPF) was added and complete solution was incubated at $37^{\circ} \mathrm{C}$ for further reaction. After incubation for $1 \mathrm{~h}$ reaction was terminated using Tris buffer $(\mathrm{pH} 12,0.1 \mathrm{M})$ and $1 \mathrm{ml} \mathrm{CaCl}_{2}$. Reaction mixture was filtered. Alkaline phosphatase was quantified by taking absorbance of product p- Nitrophenol (PNP) at $400 \mathrm{~nm}$.

\section{$\beta$-glucosidase activity}

In a test tube, $0.25 \mathrm{~mL}$ toluene, $1 \mathrm{~mL}$-nitrophenyl-Dglucoside (pNPBG), $4 \mathrm{ml}$ adjusted universal buffer with $\mathrm{pH} 6.0$ were applied to $1 \mathrm{~g}$ dry soil. Tubes were incubated at $37^{\circ} \mathrm{C}$ for $1 \mathrm{~h}$. In a test tube, Tris buffer (pH-12) and $\mathrm{CaCl}_{2}(1 \mathrm{ml}, 0.5 \mathrm{M})$ were added. Spectrophotometer set at $410 \mathrm{~nm}$ was used to determine the intensity of the colour developed in the soil suspension. g pNP g $\mathrm{g}^{-1}$ dry soil $\mathrm{h}^{-1}$ was used to test enzyme activity [32].

\section{Amylase activity}

One gram of soil sample was taken in a tube, phosphate buffer $(2.5 \mathrm{ml}$; pH6) and starch $(1 \%, 1 \mathrm{ml})$ was added. Tubes were kept at $30^{\circ} \mathrm{C}$ for $6 \mathrm{~h}$ in incubator shaker and centrifuged at $12000 \mathrm{rpm}$ for $10 \mathrm{~min}$. Supernatant $(1 \mathrm{ml})$ were taken in another tube and DNS $(1 \mathrm{ml})$ was added and placed in water bath at $90^{\circ} \mathrm{C}$ for $5 \mathrm{~min}$. Intensity of coloured product was measured by taking the readings at $540 \mathrm{~nm}[33]$.

\section{Arylesterase}

One gram soil was taken in a test tube MUB $(2 \mathrm{ml})$ and $200 \mathrm{mM}$ pNPA $(0.5 \mathrm{ml})$ were added. Tubes were placed in water bath with constant shaking for $1 \mathrm{~h}$ and centrifuged at $6500 \mathrm{rpm}$ for $5 \mathrm{~min}$ at $4^{\circ} \mathrm{C}$. Supernatant $(1 \mathrm{ml})$ was taken in another tube and $n$-hexane $(2 \mathrm{ml})$ was added. $0.5 \mathrm{ml}$ of aqueous layer was taken; $0.5 \mathrm{ml} \mathrm{NaOH}$ and ddw $(4 \mathrm{ml})$ were added. Absorbance was taken at $400 \mathrm{~nm}$ [34].

\section{Quantative PCR ( $q P C R$ ) analysis of 165 rDNA}

Soil DNA was extracted from different rhizospheric soil samples. One gram soil was used for DNA extraction using Soil DNA Purification Kit (HiMedia). Soil DNA was quantified and purity was checked in a NanoDrop spectrophotometer at 260 and $280 \mathrm{~nm}$. qPCR was performed in $\mathrm{iCycler} \mathrm{iQ}^{\mathrm{TM}}$ Multicolor instrument. Universal primers 
(EUB 341F- $5^{\prime}$ CCTACGGGAGGCAGCAG $3^{\prime}$ and EUB 534R- 5' ATTACCGCGGCTGCTGG $3^{\prime}$ ) was used to carry out real-time PCR to quantify $16 \mathrm{~S}$ rDNA in the extracted soil DNA [35]. Total volume of qPCR reaction was $25 \mu \mathrm{l}$ containing, $0.5 \mu \mathrm{l}$ of individual primer, SYBR green $(12.5 \mu \mathrm{l})$ supermix and $1 \mu \mathrm{l}$ of soil DNA (10 ng). Melt curve analysis of $16 \mathrm{~S}$ rDNA amplicons was also performed at the end of the q-PCR to ensure the amplification of $16 \mathrm{~S}$ rDNA during real-time quantification.

\section{Soil protein extraction}

One gram soil from different samples were incubated in nutrient broth $(100 \mathrm{ml})$ for $24 \mathrm{~h}$ at $27^{\circ} \mathrm{C}$ and then centrifuged for $10 \mathrm{~min}$ at $10,000 \mathrm{rpm}$. Pellet was washed in Tris/ $\mathrm{HCl}$ with pH: 6.8 and $200 \mu \mathrm{l}$ Tris buffer (pH6.8) and then centrifuged for $5 \mathrm{~min}$. Supernatant was discarded and pellet was dissolved in $200 \mu$ l extraction buffer and boiled for $20-30 \mathrm{~min}$ in water bath. Samples were centrifuged at $5000 \mathrm{rpm}$ and supernatant was used for further studies.

\section{SDS PAGE (sodium dodecyl sulphate-polyacrylamide gel electrophoresis)}

SDS PAGE performed by using $12 \%$ resolving gel and stacking gel (4\%). Protein samples for different treatments were ready in extraction buffer. Page Ruler prestained protein ladder was used as a molecular marker. The protein gel after sample loading were run using Tris glycine buffer for $6 \mathrm{~h}$ at $100 \mathrm{~V}$. Gel was fixed for $30 \mathrm{~min}$ with methanol and glacial acetic acid. Gel was stained with CBBR-250, glacial acetic acid (10\%) and methanol (10\%) with mild shaking overnight. Gel was detained for sometimes with methanol and glacial acetic acid [36].

\section{Statistical analysis}

Results were statistically analysed through Two Way Analysis of Variance (ANOVA) at $p<0.05$ using SPSS software. The values of above parameters were expressed as mean $\pm S D$ (standard deviation). Distance measure in different treatments using Heatmap with Spearman rank correlation test.

\section{Results}

\section{Seed germination assay}

Maize seeds treated with nanophos positively influenced the seed germination rate. Treated seeds showed higher (95\%) seed germination rate significantly high as compared to control (80\%) respectively.

\section{Plant growth parameters}

Four plants per plot (total 12 plants) were taken for the evaluation of agronomical and biochemical analysis. The data presented in Fig. 1 showed response of nanophos on plant height and number of leaves. 16.89 and $9.94 \%$ increase plant height were observed in nanophos treated soil in comparison to control after 20 and 40 days of sowing. Root length showed 53.76, 54.71 and $48.75 \%$ increase in nanophos treated plants and showing the $p$ value less than $P<0.05$ means statically different but moderately correlated to the control estimated using Spearman correlation test for plant height and root length (SM1). Overall enhancement in leaf area, leaf number and fresh/ dry weight of shoot/root was observed nanophos treatment over control but not statically different having the $\mathrm{p}$ value greater than $P>0.05$ (SM2).

\section{Effect on biochemical parameters}

Data analysis clearly showed that there was significant increase in all photosynthetic pigments (total chlorophyll and carotenoid) of nanophos plants over control (Fig.1). Total chlorophyll content of maize leaves was found in $4.23,4.32$ and $4.55 \mathrm{mgg}^{-1}$ leaves in nanophos treated plants after 20,40 and 60 days of sowing, least was observed in control which showed 2.62, 2.66 and $2.68 \mathrm{mg} \mathrm{g}^{-1}$. Carotenoid content also followed the same pattern and showed 34.54, 48.09 and $51.90 \%$ increase in treated plants after 20, 40 and 60 DAS over control. The $p$ value for chlorophyll and carotenoid content in nanophos treated plants was $P<0.05$ statically different from the control after the 60 days and moderately correlated to each other shown in supplementary figure (SM3).

\section{Total sugar protein and phenolic content}

Biochemical attributes were enhanced by nanophos treatment. Maximum sugar level was observed in maize plants treated with nanophos showed 45.76, 37.50 and $42.56 \%$ increase after 20,40 and 60 DAS over control. Protein content in plant leaves was positively influenced by nanophos showing $30,37.50$ and $42.42 \%$ rise in protein content over control (Fig.2). Total phenolic content in treated plants showed 54.86, 59.73 and 63.05\% increase in maize plants treated with nanophos over control. The $p$ value for sugar, protein and phenols in nanophos treated plants was $P<0.05$ statically different from the control after 40 and 60 days (SM4-5).

\section{Antioxidant enzymes}

Increase in CAT activity was observed in nanophos treated plants showed 7.91, 11.23 and $18.32 \%$ increase over control. Same pattern was followed by POD and SOD activity in treated plants and showed 16.92, 28.16, $30.26 \%$ and 5.02, 10.74 and $19.28 \%$ increase in POD and SOD activity after 20,40 and 60 DAS as compared to control (Fig.2). The $p$ value for CAT activity in nanophos treated plants was $P<0.05$ statically different from the control after 20 days no more effect was observed in POD and SOD activity shown in figure (SM5-6). 

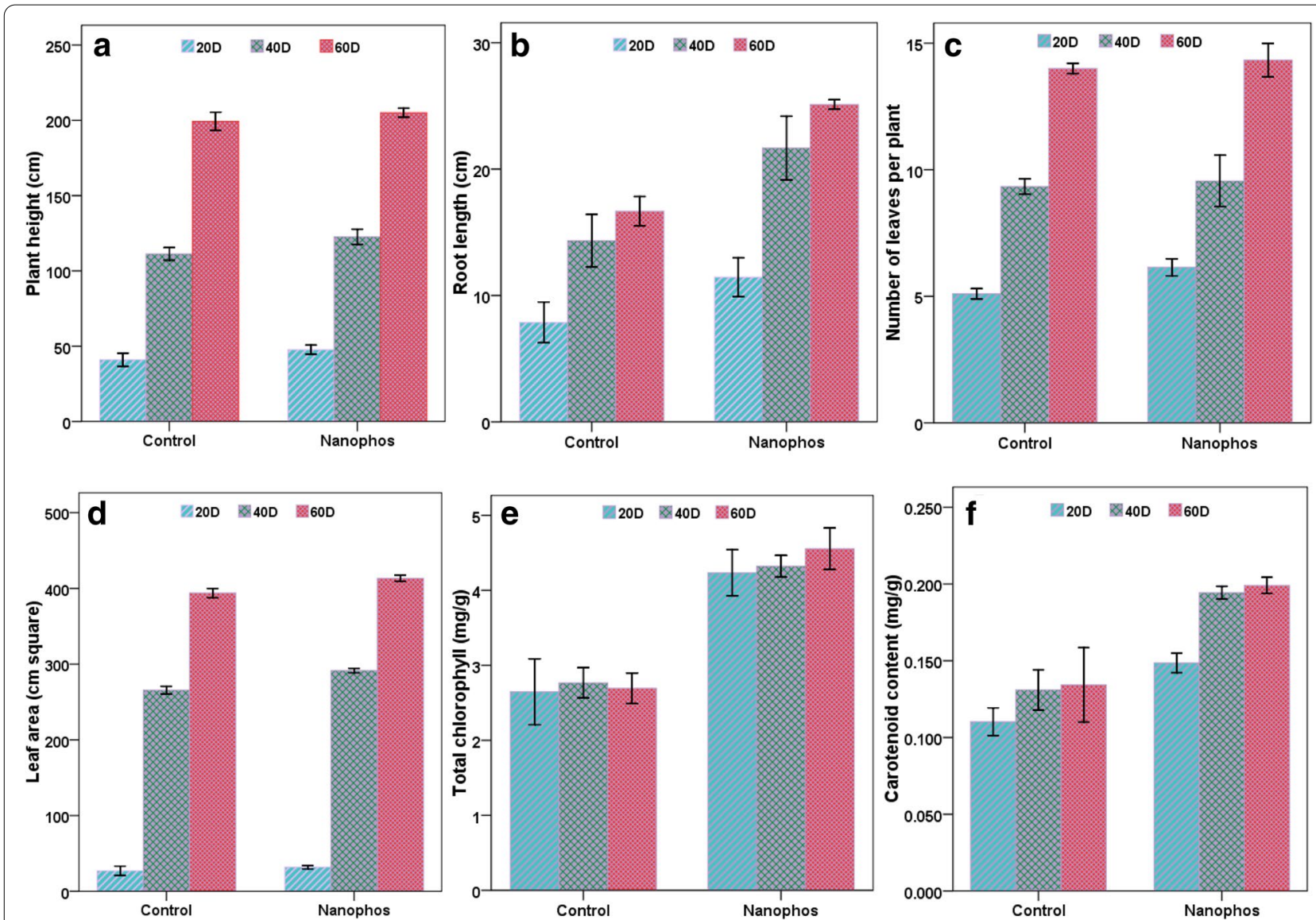

Fig. 1 Effect of nanophos on agronomical and biochemical parameters of Zea mays

\section{Maize yield}

Increase in cob weight/length about 15 and $44.83 \%$ was observed in nanophos treatment over control. Grain yield/plot showed $17.17 \%$ increase in nanophos statically different over control estimated using correlation test. Increase in 100 grain weight of seeds in nanophos was observed and showed $8.34 \%$ increase as compared to control (Fig.3).

\section{Bacterial count of treated soil on different media}

Total bacterial count in the soil treated with nanophos showed $2.28 \times 10^{6}, 2.30 \times 10^{6}$ and $2.31 \times 10^{6} \mathrm{CFU}$ while control showed $2.16 \times 10^{6}, 2.20 \times 10^{6}$ and $2.12 \times 10^{6}$ count. Colony Forming Unit of Azotobacter in nanphos treated soil was $6.76 \times 10^{5}, 6.76 \times 10^{5}$ and $7.20 \times 10^{5}$ better than the control. Number of P and K solubilizers were found maximum in treated soil showed $1.00 \times 10^{6}$ $1.01 \times 10^{6}, 1.02 \times 10^{6}$ and $6.10 \times 10^{5}, 6.33 \times 10^{5}$ and $6.23 \times 10^{5}$ after 20,40 and 60 DAS as compared to control (Table 1).

\section{Soil enzyme activities}

FDA acts as a substrate for the three enzymes protease, lipase and esterase, thus can be used as an indicator to check the activity of these enzymes. Nanophos had highest FDA hydrolysis activity $(29,29.91$ and $30.58 \mu \mathrm{g}$ fluorescein $\mathrm{g}^{-1} \mathrm{~h}^{-1}$ ) which was more than control. Activity of dehydrogenase was 5.69, 6.22 and $6.41 \mu \mathrm{g} \mathrm{TPF} \mathrm{g} \mathrm{g}^{-1} \mathrm{~h}^{-1}$ was observed in nanophos treated soil better than the control (3.61, 3.72 and $3.90 \mu \mathrm{g}$ TPF $\mathrm{g}^{-1} \mathrm{~h}^{-1}$ ). Phosphatase activity in nanophos treated soil was 308.16, 316.16 and $422.83 \mu \mathrm{gh}^{-1}$ higher as compared to control. $\beta$-glucosidase activity was 118.16, 147.66 and $153.83 \mu \mathrm{g} \mathrm{h}^{-1}$ in nanophos treated soil. Amylase enzyme activity was $71.50,75.66$ and $78 \mu \mathrm{gh}^{-1}$ in nanophos, while control showed (50.33, 51.5 and $\left.53.26 \mu \mathrm{g} \mathrm{h}^{-1}\right)$. Arylesterase activity was $109.33,111.11$ and $115.22 \mu \mathrm{gh}^{-1}$ in nanophos treated soil which was twofold increases over control (Fig. 4). The $p$ value for above enzymes $0.03,0.02$, 0.04 after 60 days of the experiment in nanophos treated plants was $P<0.05$ statically different from the control (SM7-9). 

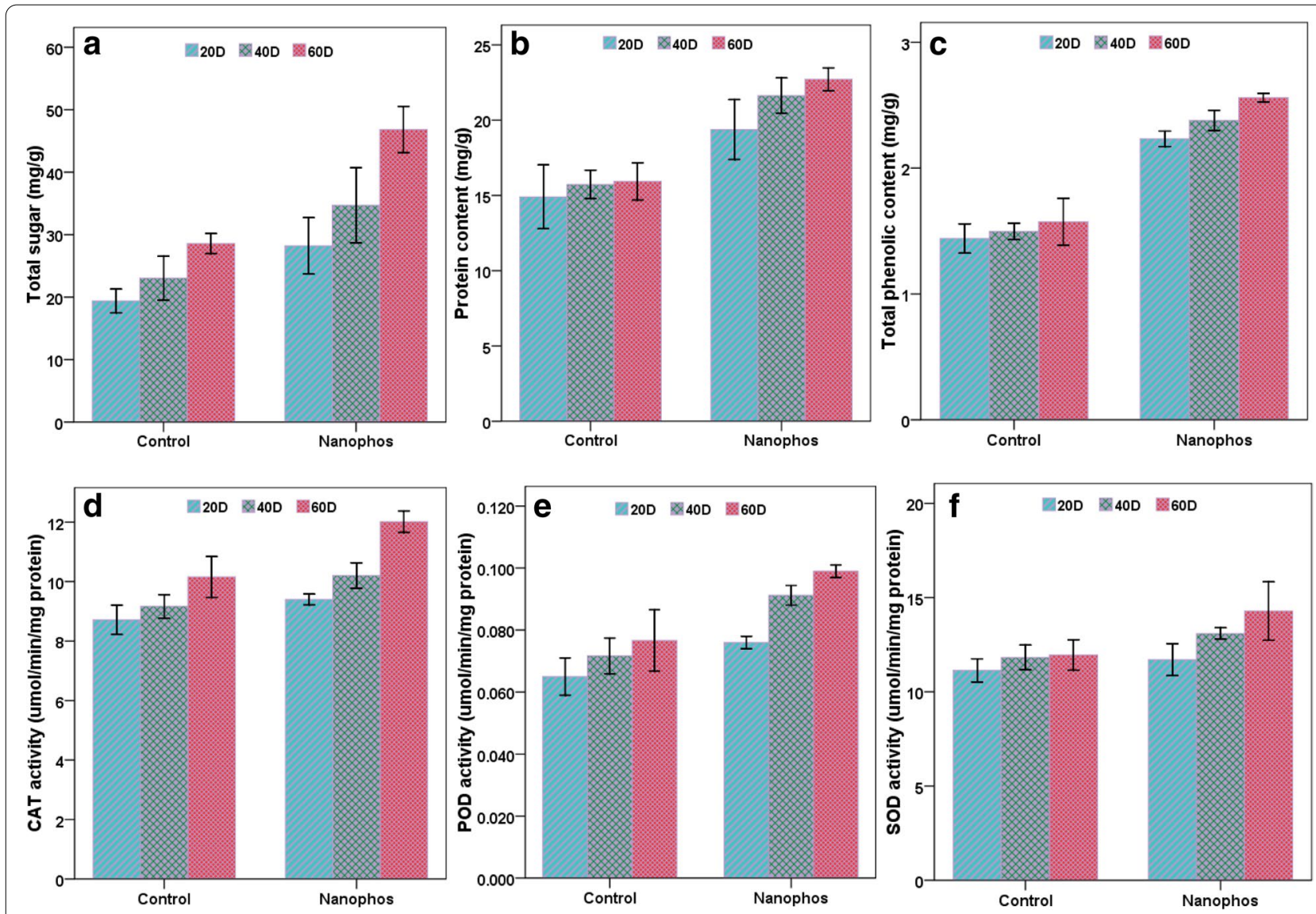

Fig. 2 Effect of nanophos on biochemical parameters and antioxidant enzyme activity of Zea mays

\section{qPCR analysis of $16 \mathrm{~S}$ rDNA}

Change in Copy number of $16 \mathrm{~S}$ rDNA per gram soil sample was evaluated using $\mathrm{GPCR}$ and the values are expressed as copy number of the bacterial community under various treatments (Table 1). Gradual increase in $16 \mathrm{~S}$ rDNA copy number up to 60 days of the experiment was observed in nanophos treated soil. Abundance of $16 \mathrm{~S}$ rDNA was $4.78 \times 10^{5}, 4.35 \times 10^{5}, 4.35 \times 10^{5}$ and $6.91 \times 10^{6}, 3.78 \times 10^{6}$ and $1.98 \times 10^{7}$ in control and nanophos treated soil respectively. The $p$ value for in nanophos treated plants was $P<0.05$ statically different from the control.

\section{Soil protein}

It was observed that treated soil has 16 and 8 prominent bands of nearly $10,13,15,16,35,40,55,70$ and $100 \mathrm{kDa}($ lane 1,2) after 20 and 60 DAS, while in control soil only 5 bands were present (lane 3,4). Intense bands were observed in nanophos soil as compared to control (SM10).

\section{Discussion}

Biofertilizers have been shown to beneficial effects on crop plant physiological action as well as soil health. Under field conditions, nanophos had a positive impact on plant and soil health parameters of Zea mays. Nanophos improved the ability of plants to absorb vital nutrients, as well as seed germination, grain maturity and crop yield. Influence of nanophos on agronomical, biochemical and yield of maize unravelling the growth promoting properties and can be useful in agricultural field. Phosphate solubilising bacteria increase the seed germination, plant/root length, leaf area and number of leaves. This may be due to the dissolving the insoluble phosphate compounds, production of phytohormones and enhancing the availability to plants by releasing organic acids and enzymes [37-39]. Biofertilizers along with nanocompounds are reported to enhance the seed germination and plant health productivity by nutrient cycling, production of plant hormones and solubilisation of different minerals [40, 41]. Combination of Bacillus megatarium, Paenibacillus polymyxa and Rhizobium promoted the shoot/root length and 

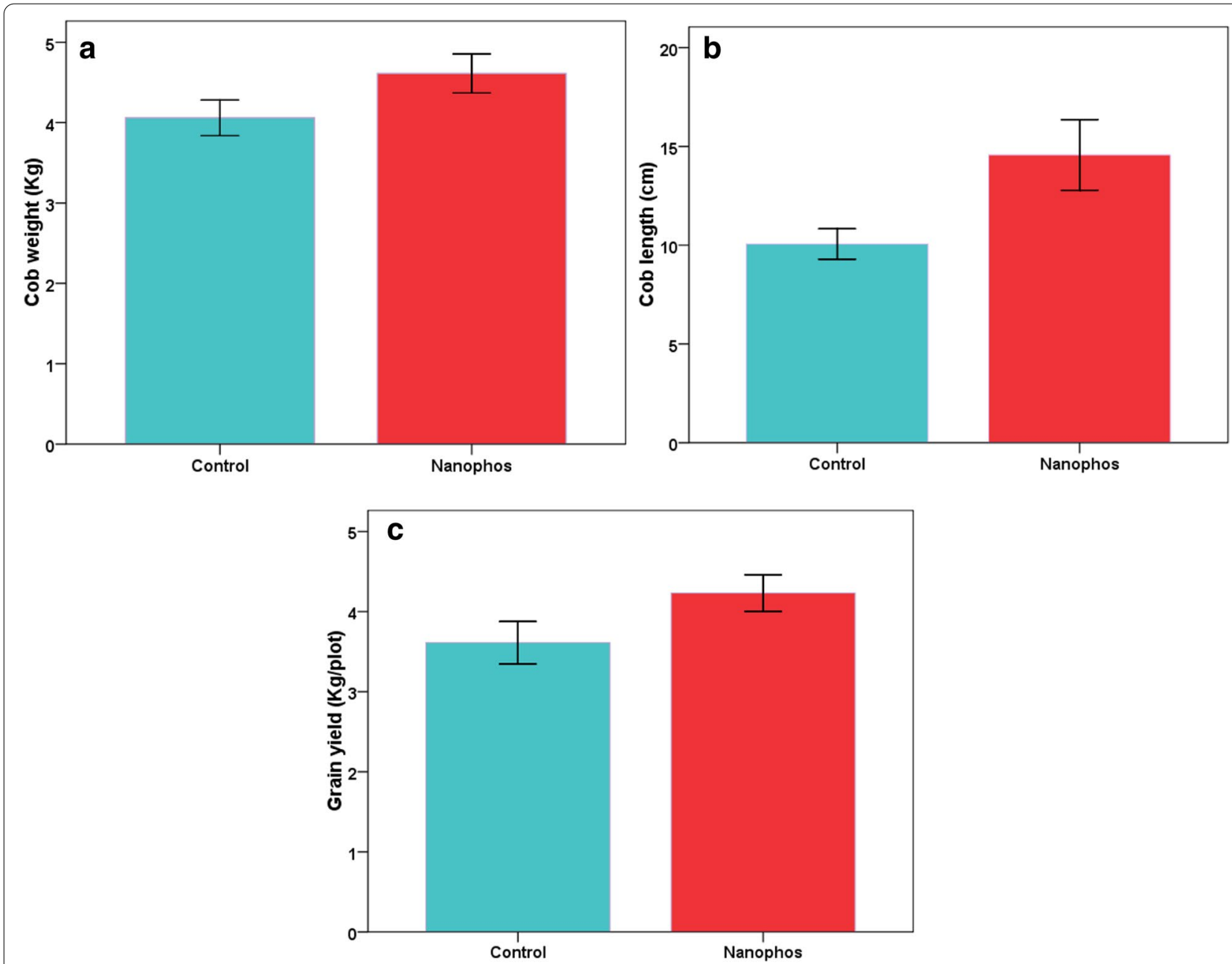

Fig. 3 Effect of nanophos on yield of Zea mays

Table 1 Effect of Nanophos on bacterial count (CFU) and 16S rDNA gene of soil

\begin{tabular}{lllll}
\hline Soil health parameters & Treatments & 20D & 40D & 60D \\
\hline Total bacterial count & Control & $2.16 \times 10^{6} \pm 4.04$ & $2.20 \times 10^{6} \pm 3.00$ & $2.12 \times 10^{6} \pm 4.50$ \\
& Nanophos & $2.28 \times 10^{6} \pm 3.00$ & $2.30 \times 10^{6} \pm 4.50$ & $2.31 \times 10^{6} \pm 5.68$ \\
Nitrogen fixing bacteria & Control & $5.40 \times 10^{5} \pm 5.71$ & $5.77 \times 10^{5} \pm 9.29$ & $5.93 \times 10^{5} \pm 5.03$ \\
& Nanophos & $6.76 \times 10^{5} \pm 5.29$ & $7.06 \times 10^{5} \pm 4.04$ & $7.20 \times 10^{5} \pm 3.58$ \\
Phosphate solubilizers & Control & $8.00 \times 10^{5} \pm 5.56$ & $8.53 \times 10^{5} \pm 4.72$ & $8.60 \times 10^{5} \pm 3.00$ \\
& Nanophos & $1.00 \times 10^{6} \pm 3.21$ & $1.01 \times 10^{6} \pm 4.21$ & $1.02 \times 10^{6} \pm 3.21$ \\
Potassium solubilizers & Control & $5.20 \times 10^{5} \pm 3.05$ & $5.40 \times 10^{5} \pm 2.64$ & $5.50 \times 10^{5} \pm 2.00$ \\
& Nanophos & $6.10 \times 10^{5} \pm 3.60$ & $6.33 \times 10^{5} \pm 4.50$ & $6.23 \times 10^{5} \pm 5.85$ \\
16S rDNA abundance & Control & $4.78 \times 10^{5} \pm 1.29 \times 10^{2}$ & $4.35 \times 10^{5} \pm 1.30 \times 10^{2}$ & $4.23 \times 10^{4} \pm 1.14 \times 10^{2}$ \\
& Nanophos & $6.91 \times 10^{6} \pm 1.10 \times 10^{2}$ & $3.78 \times 10^{6} \pm 1.05 \times 10^{2}$ & $1.98 \times 10^{7} \pm 1.20 \times 10^{2}$ \\
\hline
\end{tabular}

biomass of common bean plants due to increase the $\mathrm{P}$ availability which helps in growth and expansion of roots [42]. Bacillus mucilaginous and B. megaterium increase the phosphorus availability and chilli pepper yield in calcareous soil [43]. Bacillus spp. with phosphate fertilizer increased the yield of sugarcane under 

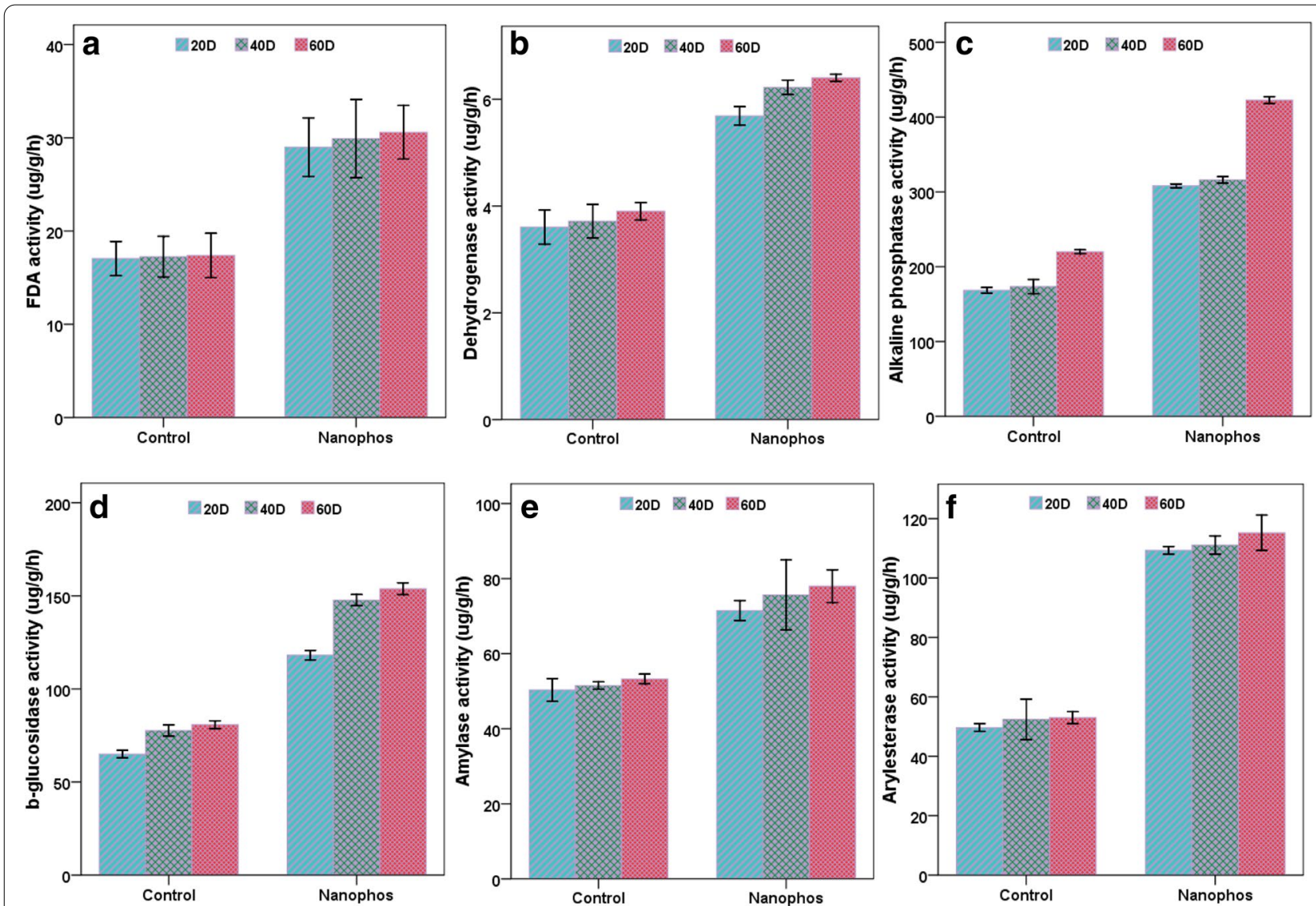

Fig. 4 Effect of nanophos on soil enzyme activities after 20,40 and 60 days of sowing

pot trial [44]. Application of nano fertilizers improved the rice yield reported by Valojai et al. [45]. Pallegrini et al. [46] reported that consortium of Gluconacetobacter diazotrophicus and Burkholderia ambifaria improved the soil nutrient status, total chlorophyll, growth and yield of onion plants. Enhanced level of antioxidant enzymes in nanophos treated plants such as CAT, POD and SOD. These enzymes can act as plant growth regulators and induce plant resistance towards phytopathogens. Nanophosphorus combination with PSB increased the total chlorophyll, SOD, CAT activity and yield of Phaseolus vulgaris significantly as compared to control in calcareous soil [47]. Bacillus amyloliquefaciens and Paraburkholderia fungorum increased the strawberry fruit growth, yield and antioxidant contents [48].

Soil NPK solubilising bacterial population also improved in nanophos treated soil. This is due to the positive impact of nanophos on bacterial community which involved in mineralization of $\mathrm{P}$ and other minerals in soil [49]. Rhizobial inoculants improved the heterotropic and P solubilizers count, higher dehydrogenase and urease activity under rye grass cultivation [50]. Biofertilizers application such as Bacillus megaterium increases the phosphorus content up to $39.7 \%$ [51, 52]. Bacillus sp. and Pseudomonas taiwanensis having the PGPR activities enhanced soil dehydrogenase, FDA, alkaline phosphatase activity, NPK solubilising population in soil and yield of maize plant under field condition $[53,54]$.

Soil enzymes are too susceptible and can be used as an indicator to analyse soil health. Different soil enzymes were significantly improved in treated soil indicating no negative impact of nanophos on soil health. Kumari et al. [55] found that nanophos $\left(2 \mathrm{ml} \mathrm{L}^{-1}\right)$ improved the soil enzyme activities like urease, dehydrogenase and alkaline phosphatase under groundnut cultivation over control. Application of B. aryabhattai and Pseudomonas auricularis improved NPK content of the rhizospheric soil and photosynthetic efficiency in Camellia oleifera plants [56]. PGPR involved in enhancement of soil beneficial community and enhanced the soil enzyme activities [57, 58]. Application of Bacillus spp. improved maize growth and soil fertility by improving 
the nutrient status of the soil [59-61]. PSB increased the urease and dehydrogenase activity [62]. Pseudomonas, Paraburkholderia and Ochrobactrum (PSB) significantly improved the nutrient status and soil enzyme activities of the soil under Chinese fir seedlings [63]. Pyrosequencing approaches revealed that application of PSB on Ulmus Chenmoui favoured the bacterial population to certain extent and improved soil fertility [64, 65]. Ren et al. [66] reported that Bacillus megatherian along with biochar increase the NPK concentration and soil urease activity. Soil NPK content and phosphatase activity were enhanced when treated with PSB under wheat cultivation [67]. Bacillus spp. improved the Proteobacteria, Chloroflexi and Bacteriodetes population and improved the soil physicochemical properties under acid mine drainage [68].

Proteomics is a valuable method for inspecting the variation in protein profiles of microbes. A minor alteration in the environment can change the amount and expression of proteins in microbes. Soil protein assessed the organically bound nitrogen that can be mineralized using microbes and can be accessible towards plants. Proteomic divergence of soil is also a sign of multifaceted microbial dynamics. The majority of the extracellular enzymes secreted by microbes such as proteases, alkaline phosphatases, lipases and cellulases comes under the range of $20-200 \mathrm{kDa}$ [69]. Alkaline phosphatase and glucosidase are essential for nutrient cycling and have a molecular weight of $80-90 \mathrm{kDa}$ [70]. The banding pattern on the gel was better in treated sample, indicating a positive association between soil enzymes and soil microbes.

\section{Conclusion and recommendations}

According to the findings of this study, nanophos has positive impact on maize agronomical, biochemical parameters, antioxidant enzymes, yield of maize and soil microbial population in maize crop. Nanophos treatment indicates good response towards total bacterial, NPK solubilising bacteria, soil enzymes and soil protein. It can be a potential way to enhance nutrient use efficiency in soil and can be a good alternative to agrochemicals used in the agricultural fields. However, more research is required in diverse environment to know the precise mechanisms of nanophos .

\section{Abbrevations}

PSB: Phosphate solubilizing bacteria; CAT: Catalase; POD: Peroxidase; SOD: Superoxide dismutase; FDA: Fluorescein diacetate; SDS: Sodium dodecyl sulphate.

\section{Supplementary Information}

The online version contains supplementary material available at https://doi. org/10.1186/s12870-021-03298-7.

Additional file 1 : SM1. Correlation analysis in control and nanophos treated sample after 20,40 and 60 days. The darker the square is, the greater the $P$-value is. The values are calculated through Spearman analysis. SM2. Correlation analysis in control and nanophos treated sample after 20, 40 and 60 days. The darker the square is, the greater the $P$-value is. The values are calculated through Spearman analysis. SM3. Correlation analysis in control and nanophos treated sample after 20, 40 and 60 days. The darker the square is, the greater the $P$-value is. The values are calculated through Spearman analysis. SM4. Correlation analysis in control and nanophos treated sample after 20, 40 and 60 days. The darker the square is, the greater the $P$-value is. The values are calculated through Spearman analysis. SM5. Correlation analysis in control and nanophos treated sample after 20, 40 and 60 days. The darker the square is, the greater the $P$-value is. The values are calculated through Spearman analysis. SM6. Correlation analysis in control and nanophos treated sample after 20, 40 and 60 days. The darker the square is, the greater the $P$-value is. The values are calculated through Spearman analysis. SM7. Correlation analysis in control and nanophos treated sample after 20,40 and 60 days. The darker the square is, the greater the $P$-value is. The values are calculated through Spearman analysis. SM8. Correlation analysis in control and nanophos treated sample after 20, 40 and 60 days. The darker the square is, the greater the $P$-value is. The values are calculated through Spearman analysis. SM9. Correlation analysis in control and nanophos treated sample after 20, 40 and 60 days. The darker the square is, the greater the $P$-value is. The values are calculated through Spearman analysis. SM10. SDS-PAGE photograph of soil protein in nanophos treated and control: Lane 1 and 2: nanophos treated soil after 20 and 60 days, Lane 3 and 4: control soil protein after 20 and 60 days of sowing, Lane 5: Prestained protein Ladder (10-180 kDa).

\section{Acknowledgments}

Authors acknowledge the facilities provided by the Microbiology and Agronomy Department of GBPU\&T, Pantnagar.

\section{Authors' contributions}

$P C$ : experimental design and wrote the manuscript, AC: data analysis; HP, AS, GK: editing the language of manuscript, RK, AS: experimental design and provided lab and field facilities to conduct this research. All the authors have read and approved the manuscript.

\section{Funding}

Not applicable.

Availability of data and materials

All the relevant data are within the paper.

\section{Declarations}

Ethics approval and consent to participate

Not applicable.

\section{Consent for publication}

Not applicable.

Competing interests

The authors declare that they have no competing interests.

\section{Author details}

${ }^{1}$ Department of Microbiology, College of Basic Sciences and Humanities, G.B. Pant University of Agriculture and Technology, Pantnagar, Uttarakhand, India. ${ }^{2}$ School of Agriculture and Environmental Sciences, Shobhit University, Gangoh, Uttar Pradesh, India. ${ }^{3}$ Department of Microbiology, Gurukula Kangri Vishwavidyalaya, Haridwar, Uttarakhand, India. ${ }^{4}$ Crop Production Division, Central Institute for Subtropical Horticulture, Lucknow, Uttar Pradesh, India. 
${ }^{5}$ Department of Agronomy, College of Agriculture, G.B. Pant University of Agriculture and Technology, Pantnagar, Uttarakhand, India.

Received: 30 May 2021 Accepted: 11 October 2021

Published online: 08 November 2021

\section{References}

1. Vaxevanidou K, Christou C, Kremmydas GF, Georgakopoulos DG, Papassiopi N. Role of indigenous arsenate and iron (III) respiring microorganisms in controlling the mobilization of arsenic in a contaminated soil sample. Bull Environ Contam Toxicol. 2015;94(3):282-8. https://doi.org/10. 1007/s00128-015-1458-z.

2. Mahawar H, Prasanna R. Prospecting the interactions of nanoparticles with beneficial microorganisms for developing green technologies for agriculture. Environ Nanotechnol, Monit Manag. 2018;10:477-85. https:// doi.org/10.1016/j.enmm.2018.09.004.

3. Maron PA, Sarr A, Kaisermann A, Leveque J, Mathieu O, Guigue J. High microbial diversity promotes soil ecosystem functioning. Appl Environ Microbiol. 2018;84:e002738-17. https://doi.org/10.1128/AEM.02738-2717.

4. Alori ET, Glick BR, Babalola OO. Microbial phosphorus solubilization and its potential for use in sustainable agriculture. Front Microbiol. 2017;8:971. https://doi.org/10.3389/fmicb.2017.00971.

5. Wu SC, Cao ZH, Li ZG, Cheung KC, Wong MH. Effects of biofertilizer containing $\mathrm{N}$-fixer, $\mathrm{P}$ and $\mathrm{K}$ solubilizers and $\mathrm{AM}$ fungi on maize growth: a greenhouse trial. Geoderma. 2005;125:155-66. https://doi.org/10.1016/j. geoderma.2004.07.003.

6. Pii Y, Mimmo T, Tomasi N, Terzano R, Cesco S, Crecchio C. Microbial interactions in the rhizosphere: beneficial influences of plant growthpromoting rhizobacteria on nutrient acquisition process. A review. Biol Fertil Soils. 2015;51:403-15. https://doi.org/10.1007/s00374-015-0996-1.

7. Xie J, Shi H, Du Z, Wang T, Liu X, Chen S. Comparative genomic and functional analysis reveal conservation of plant growth promoting traits in Paenibacillus polymyxa and its closely related species. Sci Rep. 2016;6:112. https://doi.org/10.1038/srep21329.

8. Timmusk S, Behers L, Muthoni J, Muraya A, Aronsson AC. Perspectives and challenges of microbial application for crop improvement. Front Plant Sci. 2017:8:49. https://doi.org/10.3389/fpls.2017.00049.

9. Agri U, Chaudhary P, Sharma A. In vitro compatibility evaluation of agriusable nanochitosan on beneficial plant growth-promoting rhizobacteria and maize plant. Natl Acad Sci Lett. 2021. https://doi.org/10.1007/ s40009-021-01047-w.

10. Bashan NOGA. Inoculant formulations are essential for successful inoculation with plant growth-promoting bacteria and business opportunities. Indian Phytopathol. 2016:69:739-43.

11. Vassilev N, Vassileva M, Martos V, Garcia del Moral LF, Kowalska J, Tylkowski B, et al. Formulation of microbial inoculants by encapsulation in natural polysaccharides: focus on beneficial properties of carrier additives and derivatives. Front Plant Sci. 2020;11:270. https://doi.org/10.3389/fpls.2020.00270.

12. Mahmood A, Turgay OC, Farooq M, Hayat R. Seed biopriming with plant growth promoting rhizobacteria: a review. FEMS Microbiol Ecol. 2016;92:fiw112. https://doi.org/10.1093/femsec/fiw112.

13. Bender SF, Wagg C, van der Heijden MGA. An underground revolution: biodiversity and soil ecological engineering for agricultural sustainability. Trends Ecol Evol. 2016;31:440-52. https://doi.org/10.1016/j.tree.2016.02.016.

14. Abd-Alla MH, Nafady NA, Bashandy SR, Hassan AA. Mitigation of effect of salt stress on the nodulation, nitrogen fixation and growth of chickpea (Cicer arietinum L.) by triple microbial inoculation. Rhizosphere. 2019;10:100148. https://doi.org/10.1016/j.rhisph.2019.100148.

15. Ahmad M, Adil Z, Hussain A, Mumtaz MZ, Nafees M, Ahmad I, et al. Potential of phosphate solubilizing Bacillus strains for improving growth and nutrient uptake in mungbean and maize crops. Pak J Agric Sci. 2019;56:283-9. https://doi.org/10.21162/PAKJAS/19.7285.

16. Rosa PAL, Mortinho ES, Jalal A, Galindo FS, Buzetti S, Fernandes GC, et al. Inoculation with growth-promoting bacteria associated with the reduction of phosphate fertilization in sugarcane. Front Environ Sci. 2020;8:32. https://doi.org/10.3389/fenvs.2020.00032.

17. Lacerda-Júnior GV, Noronha MF, Cabral L, Delforno TP, de Sousa STP, Fernandes-Júnior PI, et al. Land use and seasonal effects on the soil microbiome of a Brazilian dry forest. Front Microbiol. 2019;10:648. https:// doi.org/10.3389/fmicb.2019.00648.

18. Lopes CM, Silva AMM, Estrada-Bonilla GA, Ferraz-Almeida R, Vieira JLV, Otto $R$, et al. Improving the fertilizer value of sugarcane wastes through phosphate rock amendment and phosphate-solubilizing bacteria inoculation. J Clean Prod. 2021;298:126821. https://doi.org/10.1016/j.jclepro. 2021.126821.

19. Chaudhary P, Khati P, Chaudhary A, Gangola S, Kumar R, Sharma A. Bioinoculation using indigenous Bacillus spp. improves growth and yield of Zea mays under the influence of nanozeolite. 3Biotech. 2021;11:11. https://doi.org/10.1007/s13205-020-02561-2.

20. Chaudhary P, Khati P, Gangola S, Kumar A, Kumar R, Sharma A. Impact of nanochitosan and Bacillus spp. on health, productivity and defence response in Zea mays under field condition. 3. Biotech. 2021;11:237. https://doi.org/10.1007/s13205-021-02790-z.

21. Hiscox JD, Israelstam GF. A method for the extraction of chlorophyll from leaf tissue without maceration. Can J Bot. 1979;57:1332-4. https://doi. org/10.1139/b79-163.

22. Kirk JT, Allen RL. Dependence of chloroplast pigment synthesis on protein synthesis: effect of actidione. Biochem Biophys Res Commun. 1965;21:523-30. https://doi.org/10.1016/0006-291x(65)90516-4.

23. Dubois KA, Gilles JK, Hamilton PA, Rebers FS. Calorimetric method for determination of sugars and related substances. Anal Chem. 1956;28:350-6. https://doi.org/10.1021/ac60111a017.

24. Bradford MM. A rapid and sensitive method for the quantitation of microgram quantities of protein utilizing the principle of protein-dye binding Anal Biochem. 1976;72:248-54. https://doi.org/10.1016/0003-2697(76) 90527-3.

25. Ainsworth EA, Gillespie KM. Estimation of total phenolic content and other oxidation substrates in plant tissues using Folin-Ciocalteu reagent. Nat Protoc. 2007:2:875-7. https://doi.org/10.1038/nprot.2007.102.

26. Chandlee JM, Scandalios JG. Analysis of variants affecting the catalase developmental program in maize scutellum. Theoretical Appl Genet. 1984;69:71-7. https://doi.org/10.1007/BF00262543.

27. Mali PC, Vyas SP, Satish LL. Biochemical components of clusterbean genotypes in relation to bacterial blight. Indian Phytopathol. 1989:42:559-61.

28. Giannopolitis CN, Ries SK. Superoxide dismutases I. occurrence in higher plants. Plant Physiol. 1977;59:309-14. https://doi.org/10.1104/pp.59.2.309.

29. Schnurer J, Rosswall T. Fluorescein diacetate hydrolysis as a measure of total microbial activity in soil and litter. Appl Environ Microbiol. 1982;43:1256-61. https://doi.org/10.1128/AEM.43.6.1256-1261.1982.

30. Casida L Jr, Klein D, Santoro T. Soil dehydrogenase activity. Soil Sci. 1964;98:371-7.

31. Tabatabai MA, Bremner JM. Use of p-nitrophenyl phosphate for assay of soil phosphatise activity. Soil Biol Biochem. 1969;1(4):301-7. https://doi. org/10.1016/0038-0717(69)90012-1.

32. Tabatabai MA. Soil enzymes. In: Weaver RW, Angle JS, Bottomley PS, editors. Methods of soil analysis, part 2. Microbiological and biochemical properties. Madison: Soil Science Society of America; 1994a. p. 775-833.

33. Bernfeld P. Enzymes of starch degradation and synthesis. Adv Enzymol Relat Subj Biochem. 1951;12:379-428. https://doi.org/10.1002/97804 70122570.ch7.

34. Nakamura T, Mochida K, Ozoe Y, Ukawa S, Sakai M, Mitsugi S. Enzymological properties of three soil hydrolases and effects of several pesticides on their activities. J Pesticide Sci (Japan). 1990;15:593-8.

35. Muyzer G, De Waal EC, Uitterlinden AG. Profiling of complex microbial populations by denaturing gradient gel electrophoresis analysis of polymerase chain reaction-amplified genes coding for 165 rRNA. Appl Environ Microbiol. 1993;59:695-700.

36. Laemmli UK. Cleavage of structural proteins during the assembly of the head of bacteriophage T4. Nature. 1970;227:680-5. https://doi.org/10. 1038/227680a0.

37. Bashan Y, Kamnev AA, de Bashan LE. A proposal for isolating and testing phosphate-solubilizingbacteria that enhance plant growth. Biol Fertil Soils. 2013;49:1-2. https://doi.org/10.1007/s00374-012-0756-4.

38. Chaudhary P, Sharma A. Response of nanogypsum on the performance of plant growth promotory Bacteria recovered from nanocompound infested agriculture field. Envi Ecol. 2019;37(1B):363-72.

39. Kour D, Rana KL, Yadav AN, Sheikh I, Kumar V, Dhaliwal HS, et al. Amelioration of drought stress in foxtail millet (Setaria italica L.) by P-solubilizing drought-tolerant microbes with multifarious plant growth promoting 
attributes. Environ Sustain. 2020;3:23-34. https://doi.org/10.1007/ s42398-020-00094-1.

40. Khati P, Chaudhary P, Gangola S, Sharma A. Influence of nanozeolite on plant growth promotory bacterial isolates recovered from nanocompound infested agriculture field. Environ Eco. 2019b;37(2):521-7.

41. Kour D, Rana KL, Yadav AN, Yadav N, Kumar M, Kumar V, et al. Microbial biofertilizers: bioresources and eco-friendly technologies for agricultural and environmental sustainability. Biocatal Agric Biotechnol. 2020;23:101487. https://doi.org/10.1016/j.bcab.2019.101487.

42. Korir H, Mungai NW, Thuita M, Hamba Y, Masso C. Co-inoculation effect of rhizobia and plant growth promoting rhizobacteria on common bean growth in a low phosphorus soil. Front Plant Sci. 2017;8:141. https://doi. org/10.3389/fpls.2017.00141.

43. Zhao Y, Zhang M, Yang W, Di HJ, Ma L, Liu W, et al. Effects of microbial inoculants on phosphorus and potassium availability, bacterial community composition, and chili pepper growth in a calcareous soil: a greenhouse study. J Soil Sediment. 2019;19:3597-607. https://doi.org/10. 1007/s11368-019-02319-1.

44. Chungopast S, Thongjoo C, Islam AKMM. Efficiency of phosphate-solubilizing bacteria to address phosphorus fixation in Takhli soil series: a case of sugarcane cultivation. Thailand Plant Soil. 2021;460:347-57. https://doi. org/10.1007/s11104-020-04812-w.

45. Valojai STS, Niknejad Y, Amoli HF, Tari TB. Response of rice yield and quality to nano-fertilizers in comparison with conventional fertilizers; 2021. https://doi.org/10.1080/01904167.2021.1884701.

46. Pallegrini M, Spera DM, Ercole C, Gallo MD. Allium cepa L. inoculation with a consortium of plant growth-promoting bacteria: effects on plants, soil, and the autochthonous microbial community. Microorganisms. 2021;9:639. https://doi.org/10.3390/microorganisms9030639.

47. Rady MM, El-Shewy AA, Seif El-Yazal MA, El-Gawwad IFM. Integrative application of soil P-solubilizing bacteria and foliar nano P improves Phaseolus vulgaris plant performance and antioxidative defense system components under calcareous soil conditions. J Soil Sci Plant Nutr. 2020;20:820-39. https://doi.org/10.1007/s42729-019-00168-y.

48. Rahman M, Sabir AA, Mukta JA. Plant probiotic bacteria Bacillus and Para burkholderia improve growth, yield and content of antioxidants in strawberry fruit. Sci Rep. 2018;8:2504.

49. Prodhan MA, Finnegan PM, Lambers H. How does evolution in phosphorus-impoverished landscapes impact plant nitrogen and sulfur assimilation? Trends Plant Sci. 2019;24:69-82. https://doi.org/10.1016/j. tplants.2018.10.004.

50. Benidire L, Madline A, Pereira SIA, Castro PML, Boularbah A. Synergistic effect of organo-mineral amendments and plant growth-promoting rhizobacteria (PGPR) on the establishment of vegetation cover and amelioration of mine tailings. Chemosphere. 2021;262:127803. https:// doi.org/10.1016/j.chemosphere.2020.127803.

51. Fitriatin BN, Suryatmana P, Yuniarti A, Istifadah N. The application of phosphate solubilizing microbes biofertilizer to increase soil $p$ and yield of maize on ultisols Jatinangor. In: KnE life sciences; 2017. p. 179-84. https:// doi.org/10.18502/kls.v2i6.1037.

52. Saeid A, Prochownik E, Dobrowolska-Iwanek J. Phosphorus solubilization by Bacillus species. Molecules. 2018;23:2897. https://doi.org/10.3390/ molecules23112897.

53. Chaudhary P, Sharma A, Chaudhary A, Khati P, Gangola S, Maithani D. Illumina based high throughput analysis of microbial diversity of rhizospheric soil of maize infested with nanocompounds and Bacillus sp. App Soil Ecol. 2021;159:103836. https://doi.org/10.1016/j.apsoil.2020.103836.

54. Chaudhary P, Khati P, Chaudhary A, Maithani D, Kumar G, Sharma A. Cultivable and metagenomic approach to study the combined impact of nanogypsum and Pseudomonas taiwanensis on maize plant health and its rhizospheric microbiome. PLoS One. 2021;16(4):e0250574. https://doi. org/10.1371/journal.pone.0250574.

55. Kumari MS, Rao PC, Padmaja G, Ramulu V, Saritha JD. Effect of different sources of phosphorus on soil enzymes activity in groundnut (Arachis hypogaea L). Int J Curr Microbiol App Sci. 2018;7:340-9. https://doi.org/ 10.20546/ijcmas.2018.707.041.

56. Wu F, Li J, Chen Y, Zhang L, Zhang Y, Wang S, et al. Effects of phosphate solubilizing bacteria on the growth, photosynthesis, and nutrient uptake of Camellia oleifera Abel. Forests. 2019;10:348. https://doi.org/10.3390/ f10040348.

57. Kumari S, Sharma A, Chaudhary P, Khati P. Management of plant vigor and soil health using two agriusable nanocompounds and plant growth promotory rhizobacteria in fenugreek. 3Biotech. 2020;10:461. https://doi. org/10.1007/s13205-020-02448-2.

58. Kukreti B, Sharma A, Chaudhary P, Agri U, Maithani D. Influence of nanosilicon dioxide along with bioinoculants on Zea mays and its rhizospheric soil. 3Biotech. 2020;10:345. https://doi.org/10.1007/s13205-020-02329-8.

59. Kumari H, Khati P, Gangola S, Chaudhary P, Sharma A. Performance of plant growth promotory rhizobacteria on maize and soil characteristics under the influence of $\mathrm{TiO}_{2}$ nanoparticles. Pantnagar J Res. 2021;19:28-39.

60. Khati P, Chaudhary P, Gangola S, Bhatt P, Sharma A. Nanochitosan supports growth of Zea mays and also maintains soil health following growth. 3Biotech. 2017;7:81. https://doi.org/10.1007/s13205-017-0668-y.

61. Khati P, Bhatt P, Nisha KR, Sharma A. Effect of nanozeolite and plant growth promoting rhizobacteria on maize. 3Biotech. 2018;8:141. https:// doi.org/10.1007/s13205-018-1142-1.

62. Shahzad SM, Arif MS, Riaz M, Ashraf M, Yasmeen T, Zaheer A, et al. Interaction of compost additives with phosphate solubilizing rhizobacteria improved maize production and soil biochemical properties under dryland agriculture. Soil Tillage Res. 2017;174:70-80. https://doi.org/10. 1016/j.still.2017.06.004.

63. Chen J, Zhao G, Wei Y, Dong Y, Hou L, Jiao R. Isolation and screening of multifunctional phosphate solubilizing bacteria and its growth-promoting effect on Chinese fir seedlings. Sci Rep. 2021;11:9081. https://doi.org/ 10.1038/s41598-021-88635-4.

64. Song J, Min L, Wu J, He Q, Chen F, Wang Y. Response of the microbial community to phosphate-solubilizing bacterial inoculants on Ulmus chenmoui Cheng in Eastern China. PLoS One. 2021;16:e0247309. https:// doi.org/10.1371/journal.pone.0247309.

65. Khati P, Sharma A, Chaudhary P, Singh AK, Gangola S, Kumar R. Highthroughput sequencing approach to access the impact of nanozeolite treatment on species richness and eveness of soil metagenome. Biocatalysis Agri Biotech. 2019;20:101249. https://doi.org/10.1016/j.bcab.2019. 101249.

66. Ren CJ, Chen J, Deng J, Zhao FZ, Han XH, Yang GH, et al. Response of microbial diversity to $\mathrm{C}: \mathrm{N}$ : P stoichiometry in fine root and microbial biomass following afforestation. Biol Fertil Soils. 2019;53:457-68.

67. Suleman M, Yasmin S, Rasul M, Yahya M, Atta BM, Mirza MS. Phosphate solubilizing bacteria with glucose dehydrogenase gene for phosphorus uptake and beneficial effects on wheat. PLoS One. 2018;13:e0204408. https://doi.org/10.1371/journal.pone.0204408.

68. Daraz U, Li Y, Sun Q, Zhang M, Ahmad I. Inoculation of Bacillus spp. modulate the soil bacterial communities and available nutrients in the rhizosphere of vetiver plant irrigated with acid mine drainage. Chemosphere. 2021;263:128345. https://doi.org/10.1016/j.chemosphere.2020.128345.

69. Glenn AR. Production of extracellular proteins by bacteria. Annu Rev Microbiol. 1976;30:41-62. https://doi.org/10.1146/annurev.mi.30.100176. 000353.

70. Taylor JS, Coleman JE. Nitrogen ligands at the active site of alkaline phosphatase. Proc Natl Acad Sci U S A. 1972;69:859-62. https://doi.org/ 10.1073/pnas.69.4.859.

\section{Publisher's Note}

Springer Nature remains neutral with regard to jurisdictional claims in published maps and institutional affiliations. 